Etnográfica

Revista do Centro em Rede de Investigação em

Antropologia

vol. 14 (3) | 2010

Vol. 14 (3)

\title{
Beyond the boundaries: final comments
}

\section{Daniel Miller}

\section{CpenEdition \\ Journals}

\section{Edição electrónica}

URL: https://journals.openedition.org/etnografica/216

DOI: 10.4000/etnografica.216

ISSN: 2182-2891

\section{Editora}

Centro em Rede de Investigação em Antropologia

\section{Edição impressa}

Data de publição: 1 outubro 2010

Paginação: 587-591

ISSN: 0873-6561

\section{Refêrencia eletrónica}

Daniel Miller, «Beyond the boundaries: final comments», Etnográfica [Online], vol. 14 (3) | 2010, posto online no dia 21 outubro 2011, consultado o 12 fevereiro 2022. URL: http://journals.openedition.org/ etnografica/216 ; DOI: https://doi.org/10.4000/etnografica.216

\section{(c) (i) (9)}

Etnográfica is licensed under a Creative Commons Attribution-NonCommercial 4.0 International License. 


\section{Beyond the boundaries: final comments}

\section{Daniel Miller}

Department of Anthropology, University College London (UK)

WHAT THESE FOUR EXCELLENT PAPERS ON THE TOPIC OF CONSUMPTION have in common is that they represent a certain maturity in the anthropological scholarship regarding consumption. They are far removed from earlier more pedantic concerns with questions such as "what is consumption?" or how far should consumption be regarded as either good or bad. Rather, at this stage we can see that the earlier literature tended to simplify and narrow our discussion precisely because it remained fixated upon the foundations of our understanding of consumption as a thing in itself. While at this point we can allow ourselves to be more relaxed, to break out of such definitions and boundaries and be more true to the subtlety and complexity of our evidence.

Since these papers derive from quite different sources, it is interesting to reflect then upon what they have in common as evidence for what this contemporary phase of consumption studies is trying to achieve. I would suggest there are three common themes: the desire to transcend earlier boundaries and dichotomies, the relationship between consumption and socialization, and the importance of routine to consumption. To take the first of these, central to Marques is the way we have assumed too firm a boundary between work and leisure, central to Portilho is the need to transcend the usual contrast between the political as against the non-political, central to Rosales is the usual association of consumption with the domestic, contrasted here with the much wider spatial nexus represented by migration. In the case of Barbosa there is a particularly subtle dichotomy being transcended here between socialization as means and as ends. Since there are many references to my work I am happy to accept responsibility for these faults in earlier studies of consumption. I can certainly 
recognize places in my own writing where the dichotomy of work and leisure is overdrawn, where the domestic has become too detached from the world, and the political has been defined too narrowly, and where there has been confusion in assigning a role to socialization in and of itself within consumption.

Indeed I would say that every one of these papers could have gone even further in their repudiation of prior distinctions. Marques starts from the assumption that a woman who has her nails done, after becoming unemployed, is simply seeing work as constraint and leisure as opportunity. But through her careful analysis she entirely rejects any such interpretation. Rather she shows how for many people work is the foundation of consumption. Not just that every increase in wages can be a spur to new forms of consumption. But as Freeman (2000) showed, the workplace is often where one demonstrates and cultivates consumption, and where in relationship to other workers one creates one's expectations and personal style. Curiously, when I first worked on consumption the dominant influence was Marxism, and the only way I could get people to valorise consumption was by convincing people that consumption was a kind of work. Today consumption is so well established as a point of authentification that Marques is, in effect, having work itself valorised by a recognition that it is also an aspect of consumption. But I think she could go still further. After all, the work/leisure distinction is daily being diminished by the rise of digital technologies, where we Facebook from the office and answer e-mails from home.

In the case of Rosales, the dichotomy that must be overcome is that posed by the very concept of domesticity. As she notes, we have increasingly been exhorted to pay attention to the intimate world of the private sphere, which makes the home increasingly appear detached from the world. But by focusing on the relationship between migration and materiality, Rosales demonstrates that the home always incorporates a much wider spatial orientation to all the previous homes that a family has occupied and to which the present home may be contrasted. It is a local which has also to express an experience of the global. If we come to see the domestic as merely that within the walls, we fail to see the wider correspondence. This point has been made particularly forcefully in kinship studies, where it is now common to see the house as a metaphor for social relationships more generally (Carsten 2000; Carsten and Hugh-Jones 1995), not only in terms of extended family, but also in terms of a continuous process of evolving relationships. So perhaps we see here a confluence between anthropologists of kinship turning to this materiality and the students of the home acknowledging this sociality.

In the case of Portilho, the dichotomy is represented by the very term political. Her consumers are faced with a concept of the political that insists that unless things are done at the level of the state or through activism then the consumer represents no more than a pawn of the market. But it is clear that 
these actual consumers see things very differently. It is not that they betray the truth of politics but in some ways this very narrow conception of politics betrays them. They lose their ability to either control, take responsibility for, or identify with their own ethical actions. They also lose their ability to relate wider political consciousness to their concerns with local farmers or the health of their own family, which are both central to their interest in organic food. So they need and want their self-attribution of responsibility to be recognized as valuable political action.

When we come to Barbosa we find an alignment between this theme and the other two that I want to explore. The dichotomy that Barbosa wishes to overcome derives from the sociology of sociability itself and its idea that this can be instrumental, i.e. we associate with each other for the furtherance of some aim, or the opposite, that this is an end of itself, we consume in order to create a nexus for sociability. What she finds through the careful dissection of meal times is that food commensality is not reducible to either of these. Food consumption is simply an integral aspect of everyday life and as such will almost always include both of these concerns, it is a potential vehicle for human association which may or may not be otherwise purposeful.

The importance of this transcending of boundaries in all four papers is that it takes consumption still further away from an older semiotic tradition and, I would argue, brings it closer to that of material culture, in the sense that consumption is not there just to signify work, or locality or ethics or sociability, rather it is part of practice, which includes all these things. We eat in a particular place, with particular people and particular concerns, as is also true of making home or how we behave at work. By stepping away from definitions and boundaries we can be much more subtle about the qualities of these things. So Barbosa doesn't just critique theories of sociability, she gives us a better way of appreciating the way sociability acts within practice. So people in a home can eat in front of the television and yet this still be more part of family life than going out. In London, when you accuse someone of missing breakfast, it may be that they eat at work, so they did have a breakfast, but the problem is they didn't eat within the home. This matters even if in London, as in Brazil, no one actually talks to each other over breakfast. But socialization matters in all these cases. When Rosales sees the home as linked to past homes in other countries it is a link also to the social relations associated with those homes. Portilho is concerned to allow consumers to refuse one kind of association, that of the NGO, in order to create a more intimate socialization they can identify with more easily, while Marques shows that work itself is as much a point of socialization as alienation. So in all these cases we come to see sociability as an integral aspect of consumption.

Barbosa's paper doesn't just link breaking the boundaries with sociability, it also provides a really rather exemplary, even beautiful, sense of how 
anthropologists ought to treat the topic of routine. In this she is timely, as we have recently seen one of the first volumes specifically devoted to the issue of routine in the social science study of consumption (Shove, Trentmann and Wilk 2009). It is an important book with many good articles, but I don't think any of the papers in that volume achieve quite the same degree of overturning our identification of routine with the boring or the ordinary, and instead infuse it with something that is sensual, almost sexual. Barbosa shows that food routine in Brazil is not a constant. It gives rhythm to the week. Starting from its lowest point after the weekend it gradually moves towards greater intensity so that where you eat and how you dress becomes increasingly important, to build up through Friday and Saturday nights to the climax of Sunday lunch. It is even more remarkable that this is achieved without necessarily a particular concern for the food itself as cuisine. I recently bore witness, during a visit to Brazil, to these wonderful Sunday lunches that can last for some ten hours of blissful socialization.

Having seen this highlighted in Barbosa's work, one can also start to see the resonance of this emphasis upon routine in the other papers in this collection. Routine is equally important to Portilho's argument in that these consumers want to make ethical concerns something that is integrated into their own sense of routine, that they should see being ethical as simply part of their everyday consumption practice, the very opposite of the highly charged moment of politics. For them, making ethics routinised so far from making it less important is actually more effective and consistent than politicised ethics. Similarly, re-thinking routine is central to Marques, because what her paper accomplishes is a shift from seeing a manicure as being a sign of the break from the routines established in having to go to work every day, and instead seeing it as an attempt to retain something of the self-respect and social respect that is associated with work itself. Finally Rosales recognizes that the materiality of the home is also a grounding of one's habitual action in respect to the home, the things we walk around, sit in, and dust. As such they are the ways memory of migration becomes contemporary practice.

These are four exemplary academic papers - in each case the authors take a familiar topic and brush aside the more superficial interpretation of what we think we have seen, and reveal much deeper insights into the significance of the actions they have observed. By this stage, the study of consumption has become deeply ethnographic. They bring us the rhythms of everyday life in which one's relationship to work or leisure, migration and the past, one's ethical sense of responsibility and even the sense of what part of the week we are in, coming from this embedded practice. Never has the mundane seemed so fruitful and exciting. 


\section{REFERENCES}

CARSTEN, Janet (ed.), 2000, Cultures of Relatedness. Cambridge, Cambridge University Press. CARSTEN, Janet, and Stephen HUGH-JONES (eds.), 1995, About the House. Cambridge, Cambridge University Press.

FREEMAN, Carla C., 2000, High Tech and High Heels in the Global Economy: Women, Work, and Pink-Collar Identities in the Caribbean. Durham, Duke University Press.

SHOVE, Elizabeth, Frank TRENTMANN, and Richard WILK (eds.), 2009, Time, Consumption and Everyday Life: Practice, Materiality and Culture. Oxford, Berg Publishers. 